\title{
The first smallpox epidemic on the Canadian Plains: In the fur-traders' words
}

\author{
C Stuart Houston OC SOM DLitt MD FRCPC ${ }^{1}$, Stan Houston MD FRCPC ${ }^{2}$
}

\begin{abstract}
CS Houston, S Houston. The first smallpox epidemic on the Canadian Plains: In the fur-traders' words. Can J Infect Dis 2000;11(2):112-115.

William Tomison, in charge of the Hudson's Bay Company's Cumberland House on the Saskatchewan River, described the devastating smallpox epidemic of 1781 and 1782. He understood contagion, practised isolation and disinfection, and provided mortality statistics during a 'virgin soil' epidemic. Above all, he showed remarkable compassion. He and his men took dying Indians into their already crowded quarters, and provided them with food, shelter and $24 \mathrm{~h}$ care. This article describes the epidemic and its aftermath.
\end{abstract}

Key Words: Cree Indians; Disease outbreaks; Fur trade; Smallpox

Première épidémie de variole dans les Prairies canadiennes et... histoire du commerce de la fourrure

RÉSUMÉ : William Tomison, responsable de Cumberland House de la Compagnie de la Baie d'Hudson sur la rivière Saskatchewan, décrit la première épidémie de variole qui a eu lieu en 1781 et en 1782 et qui s'est avérée dévastatrice. Il avait déjà compris le principe de la contagion, de l'isolement et de la désinfection, et a fourni des statistiques sur la mortalité pendant une épidémie qui s'est déroulée en « terrain vierge ». Par-dessus tout, il a fait preuve d'une grande compassion. Lui et ses hommes ont accueilli des Indiens mourants dans leurs quartiers déjà surpeuplés et leur ont fourni gîte et nourriture, en plus de leur prodiguer des soins 24 heures sur 24. Le présent article décrit l'épidémie et ses conséquences.

$S$ mallpox was brought to Mexico by the Spaniards in 1520. On each occasion it occurred in epidemic form, with extremely high mortality among Aboriginal peoples who, in epidemiological terms, were 'virgin soil'. Smallpox reached Massachusetts in 1633 and the St Lawrence River in both 1635, and 1669 to 1670 . The 1702 epidemic reached as far west as Sault Sainte Marie and the 1736 to 1738 epidemic extended to Lake of the Woods, at the south-east corner of present day Manitoba (1). In the present article, we share our assessment of the first recorded smallpox epidemic on the western plains in 1780 and 1781, and its chroniclers, William Tomison and Matthew Cocking. Their conduct was exemplary, because in other parts of the Americas the response of white 'civilization' to smallpox epidemics in native communities was sometimes less than charitable. Indeed, early examples of the use of smallpox as a biological weapon through the distribution of infected blankets have been reported $(1,2)$.

Physicians today know little about the epidemiology and impact of smallpox among the Aboriginal people of western Canada or the response of the Europeans in the country, at that time mainly employees of the two major fur trading companies.

William Tomison (3) became the inland master of the Hudson's Bay Company (HBC) in 1778, only four years after Sam-

\footnotetext{
${ }^{1}$ Professor Emeritus of Medical Imaging, University of Saskatchewan, Saskatoon, Saskatchewan; ${ }^{2}$ WC Mackenzie Health Sciences Centre, University of Alberta, Edmonton, Alberta

Correspondence: Dr C Stuart Houston, 863 University Drive, Saskatoon, Saskatchewan S7N 0J8. Telephone 306-244-0742, e-mailhoustons@duke.usask.ca 


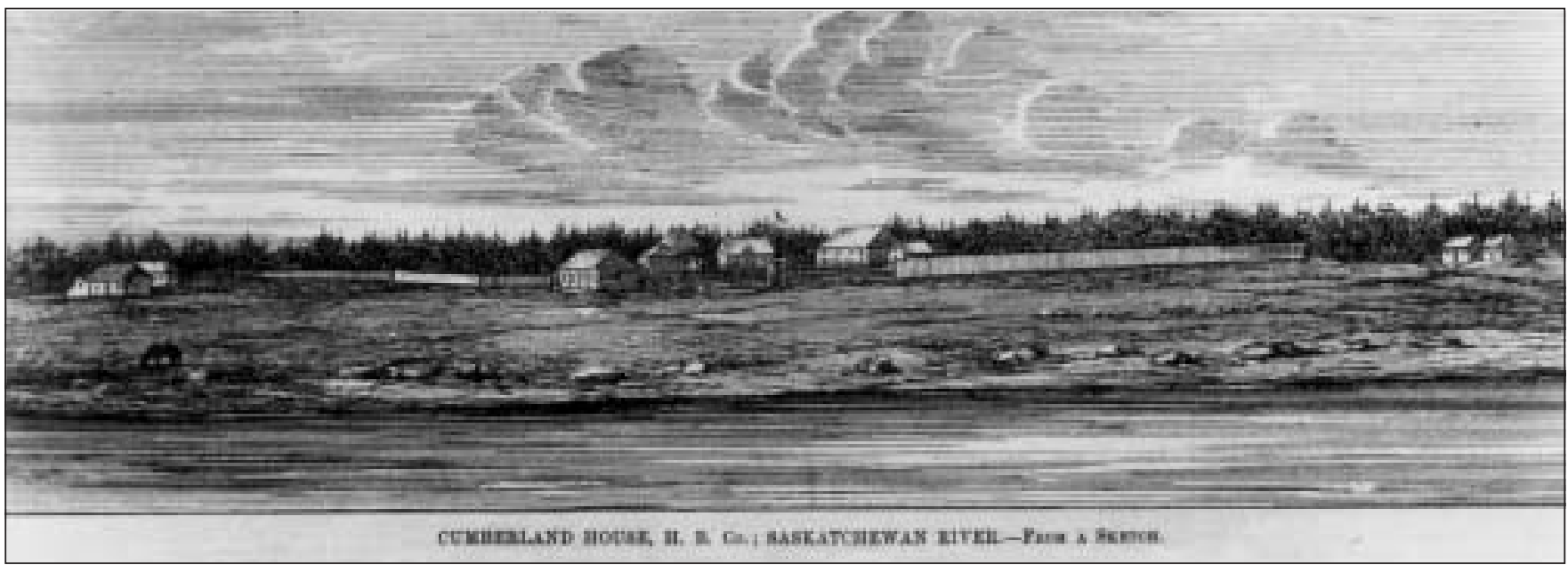

Figure 1) Cumberland House a century later (1875)

uel Hearne (4) had founded the first far inland trading post of the HBC at Cumberland House (now in Saskatchewan). Tomison's account of the smallpox epidemic of 1781 and 1782, just 20 years before Jenner published his paper on vaccination, "is the most detailed record of the first catastrophic epidemic known to have affected the native populations of the (Canadian) plains" (3).

In reading these handwritten diaries of daily events, the authors were impressed by the literary skills and perspicacity of William Tomison and Matthew Cocking (5), Tomison's predecessor at Cumberland House, Cocking was in charge at York Factory in 1781 and 1782. Both Tomison and Cocking recognized that smallpox was contagious and provided long standing immunity to the victim. Tomison clearly understood that in severe cases, death could occur during the generalized systemic (viremic) stage before the skin eruption.

Tomison saw that isolated Indian groups might escape contact with smallpox, simply by being so widely dispersed, without contact with other Indians. He explained how the very few Indians who survived smallpox might die of starvation. He tells us the probable origin of the epidemic, from Spaniards via the Snake Indians in what is now the western United States. He understood the nearly complete immunity to smallpox among Caucasian employees of the $\mathrm{HBC}$ - presumably for most of them representing acquired resistance achieved from almost universal childhood exposure in the Orkney Islands. Charles Price Isham, son of Chief Factor James Isham and an Indian woman, born in the Hudson's Bay Territory, but educated in England (6), did come down with smallpox at Lower Hudson's House but survived. Tomison's daily journal entries provide a good assessment of the mortality among Aboriginals during the 1781 and 1782 epidemic. Not surprisingly, Indian children at Cumberland House appeared to survive smallpox more frequently than did their parents, though the sample size is not sufficiently large to be conclusive.

Morbidity and mortality were extremely high, but there is no satisfactory numerator and no denominator to calculate the rates of morbidity or mortality. Many or most Indians, whom the authors classed as 'alive' when first mentioned, be- tween December 4, 1780 and March 23, 1781 (often because they had not yet been exposed) soon became ill with smallpox. Almost all of those who contracted smallpox, died. One must recognize these somewhat anecdotal entries as 'soft' data, yet one can use the daily journal entries, together with Roe's estimate of an average of seven Indians, including children, per tent (7) to estimate small pox deaths in the area tributary to Cumberland House. Such calculations yield 288 smallpox deaths, 50 sick with smallpox, and 58 alive at first mention. Only 13 Indians in this substantial region are mentioned as having recovered from smallpox, suggesting a mortality rate of up to $95 \%$.

Tomison put his knowledge to good use. He practised isolation, and used a disinfectant (sulphur). According to Professor Morton, "Fumigation with sulphur and the succession of airings in the sunshine and at the several posts and in London would have the effect of disinfecting the furs before they would reach the market. This would also go far to explain how it was that no European servant of the company took the disease" (8).

Alfred Robinson, the new surgeon at York Factory, practised quarantine of the Indian arrivals with smallpox, combined with isolation, by sending his 'Home Indians' away from the fort. Isolation and quarantine were successful. None of the Indians or Whites at York Factory came down with smallpox. While most Whites at York Factory probably were immune, as were the predominantly Orkneymen at Cumberland House, the Indians at York Factory were spared the smallpox epidemic that had ravaged the interior. Ewart's tabulation (9) of illness at York Factory showed only six cases of smallpox among Aboriginals between 1714 and 1946. All six were in 1782, and each had brought his disease with him from the plains. Measles and influenza epidemics, on the other hand, were brought by ships to York Factory and then taken inland, the opposite direction to that was followed by the smallpox virus.

Perhaps even more commendable is the remarkable compassion shown the Aboriginals by Tomison and his White employees. In their primitive and already crowded quarters at 
Cumberland House, Tomison's Caucasian HBC servants, under his direction, took in the dying Indians, provided them with food, shelter and $24 \mathrm{~h}$ care (nearly a century in advance of the arrival of Grey Nuns in the northwest), and then, in most instances, dug their graves in deeply frozen ground in midwinter.

The following are selected excerpts from the Cumberland House journals of 1781 and 1782 (10).

December 1781 17th Monday. I received the Disagreeable News of that Devouring Disorder the small pox rageing amongst the Natives $\&$ is carrying all off before It...

"Copy of a Letter received from Mr William Walker, Hudsons House [built by William Tomison in 1788, $370 \mathrm{~km} \mathrm{up-}$ stream from Cumberland House on the North Saskatchewan River], Decr 4th $1781 \ldots$ the small pox is rageing all round Us with great Violence, sparing very few that take it. We have received the News of above 9 tents of Indians within here, all Dead, the tents left Standing \& their bodies left Inside Unburied. ... the Indians lying Dead about the Barren Ground like rotten sheep, their Tents left standing \& the wild beast Devouring them."

18th Tuesday those that arrived last Night smoaking every thing belonging to them with the Flour of Sulpher [sic] to prevent any effect from them to the Natives.

25th Tuesday ... late at Night two Indian Boys ... brought the low Country lad on a Sledge. He was taken bad last night with a Violent pain in his breast $\&$ Belly ...

26th Wednesday ... The low Country Indian still continues very ill.

27th Thursday ... This Morning we could Observe the small pox coming out very thick upon the sick lads heads \& thighs.

30th Sunday ... The Indian still continues very bad, he has a great stoppage in his throat ...

1782. 1st January Tuesday. The Indian lad still very ill. He turn'd blind last Night ...

5 th Saturday. ... one man making a Coffin \& one man digging a Grave for the Indian lad, he Died last night between $9 \&$ 10 oclock \& was for 24 hours delirious.

15th Tuesday. Late in the Evening a Distressed Woman \& her Child came here, these are all that is alive out of one Tent, \& has not yet been ailing. The News she brings is still more \& more alarming ... the small pox rageing amongst them with its greatest fury, \& carrying all before it, they chiefly Die within the third or fourth Night, \& those that survive after that time are left to be devoured by the wild beasts.

25th Friday ... Two men Digging a Grave \& burying a Woman that Died last Night. There is still nine more ailing, four of which I have in the House \& they have due attendance [sic, attendants] Night \& Day \& yet there is but little hopes of their recovery.

31 st Thursday ... sent four Men to Bury four of the Indians ... Late in the Evening three Young Indians arriv'd from the U'Basquiau Leader, one of which was taken bad last night.... Out of a number that has died, there is only one Woman that has recovered. 1st February Friday. Indeed it is hard labour to keep the House in fuel and bury the Dead.

2d Saturday ... One [man] digging a Grave and burying an Indian that Died in the Night after having been taken care of in the House for these ten Days past. There is something very malignant, that we are not sensible of, either in the Constitution of the Natives or in the Disorder, those that Die before the small pox breaks out is tormented with great pains and many of them Die within 48 hours. ...

Febry 19th ... here we have buried Upwards of 30 for Which Number there is only two recovered \& they are but Children. The U'Basquiau Indians are all Dead \& ten tents of Pegagamy and Cowinetow Indians that was pitching towards this place all Died. ... am of Opinion that it has come from the snake Indians \& has been conveyed to them by those that trade in the Mississipi [sic].

March 23 Saturday ... a Boy \& Girl arrived from the Swampy River, having left one man behind, these is all that is alive out [of] 10 tents ...

The following are excerpts from the York Factory journal of Matthew Cocking, 1781 and 1782 (11).

$2 d$ July Tuesday. Mr. William Tomison and 22 Englishmen ... arrived. ...Charles Isham [at Hudson's House] had been ill of the Small Pox but happily recovered. ... The whole tribe of U'Basquia Indians are deceased except one young Child ... the many different Tribes of Southern Assinne Poet and Yatchithinue Indians are also almost wholly extinct as I am assured by MesS $^{\text {rs }}$ Tomison and Longmoor for they say that they really believe of young and old not one in fifty of those Tribes are now living.

It seems a party of those Indians who were at war having met with a Tent of Kenspick Athinewack [ie Snake] Indians who were all ill of the Small Pox (and were supposed to have received it from the Spaniards whom tis said those people trade with) killed them all and scalped them to carry away with them, by this means they received the infection and almost all of them died on their return. What few reached their own Country communicated the disorder to their Friends and it spread through the whole Country. ... Numbers died through want of Food or starved with cold having no attendance [sic, attendants] for as the complaint became general there was none left in many Tribes able to hunt for or administer to the wants of each other. Many put an end to their own existence to end their pain and others for grief at the loss of their friends.

Mr Tomison's information is additionally distressing ... he met two Canoes of the Lake Indians who arrived here the 10th Ulte and went away the 14th. These he assures me are all that remain of that Company, the rest 14 canoes being all dead of the Small Pox.

Towards noon six Canoes arrived with Furs to trade, five of them are Sahsahnew Indians, the sixth Lake Indians. Three of this Company are now ill of the Small Pox which seized them on the way down. I put them all immediately under the surgeons care; one of them died in the evening, the others have 
spots coming out on them very thick which the surgeon says have been an unfavourable appearance [they died within days] and their throats are excessive sore.

\section{CONCLUSIONS}

The smallpox epidemic among Cree Indians in western Canada describes the first major health impact of their contact with Eurpoeans. Over two centuries later, the health of Canadians Aboriginal people still compares unfavourably with that of non-Aboriginal Canadians. This is due in large part to infectious disease such as tuberculosis and, increasingly, HIV, as well as noninfectious conditions such as diabetes and substance abuse. These persisting health problems are, at least in part, the effects of European contact.

\section{REFERENCES}

1. Heagerty JJ. Four centuries of medical history in Canada, vol 1. Toronto: Macmillan, 1928:17-65.

2. Stearn EW, Stearn AE. The effect of smallpox on the destiny of the Amerindian. Boston: Bruce Humphries, 1945:44-5.
3. Nicks JS. William Tomison. In Halpenny FG, ed. Dictionary of Canadian Biography, 1821-1835. Toronto: University of Toronto Press, 1987:5:775-7.

4. Mackinnon CS. Samuel Hearne. In: Halpenny FG, ed. Dictionary of Canadian Biography, 1771-1800. Toronto: University of Toronto Press, 1979:4:339-42.

5. Spry IM. Matthew Cocking. In: Halpenny FG, ed. Dictionary of Canadian Biography, 1771-1800. Toronto: University of Toronto Press, 1979:4:156-8.

6. Brown JSH. Charles Price Isham. In: Halpenny FG, ed. Dictionary of Canadian Biography, 1801-1820. Toronto: University of Toronto Press, 1983:5:450-1.

7. Roe FG. The North American Buffalo. Toronto: University of Toronto Press, 1951:747.

8. Morton AS. 1939. A History of the Canadian West to 1870-71. London and Toronto: Thomas Nelson and Sons, 1939:333.

9. Ewart WB. Causes of mortality in a subarctic settlement (York Factory, Manitoba), 1714-1946. CMAJ 1983;129:571-4.

10. Hudson's Bay Company Archives (HBCA), Provincial Archives of Manitoba (PAM, B.239/a/80), York Factory journal, Sept 1,1781 to Aug 17, 1782 (Microfilm reel IM 159).

11. Rich EE, ed. In: Cumberland House Journals and Inland Journals, 1775-82, vol 2, 1779-1782. London: Hudson's Bay Record Society, 1952:197-291. Also HBCA, (PAM B.49/a/11), Cumberland House Post Journal, 1781-82 (Microfilm reel IM 38). 


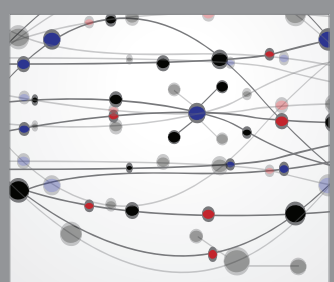

The Scientific World Journal
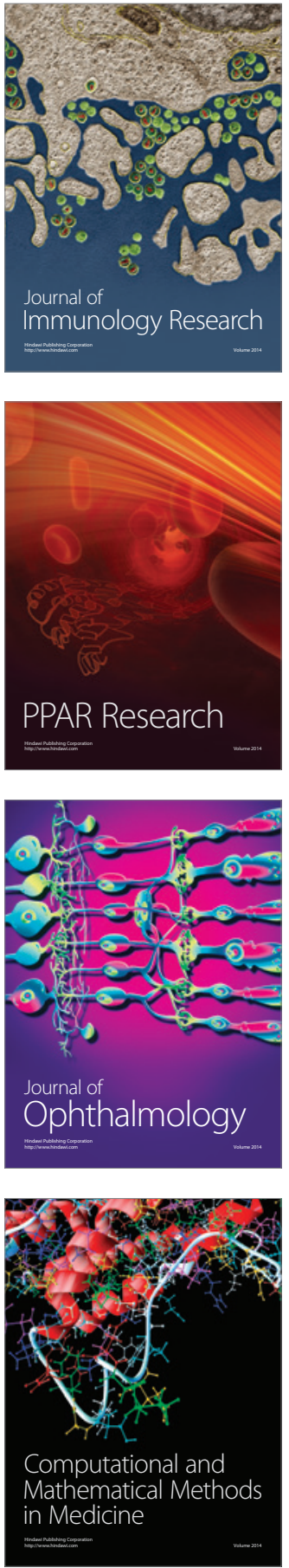

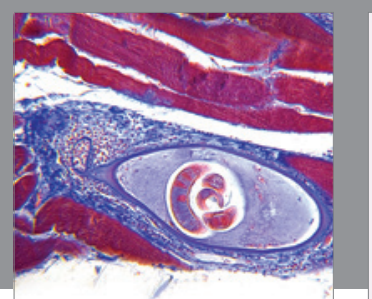

Gastroenterology Research and Practice

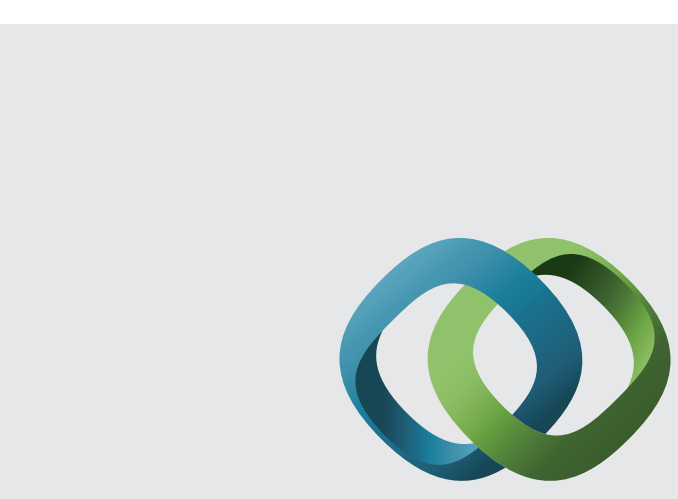

\section{Hindawi}

Submit your manuscripts at

http://www.hindawi.com
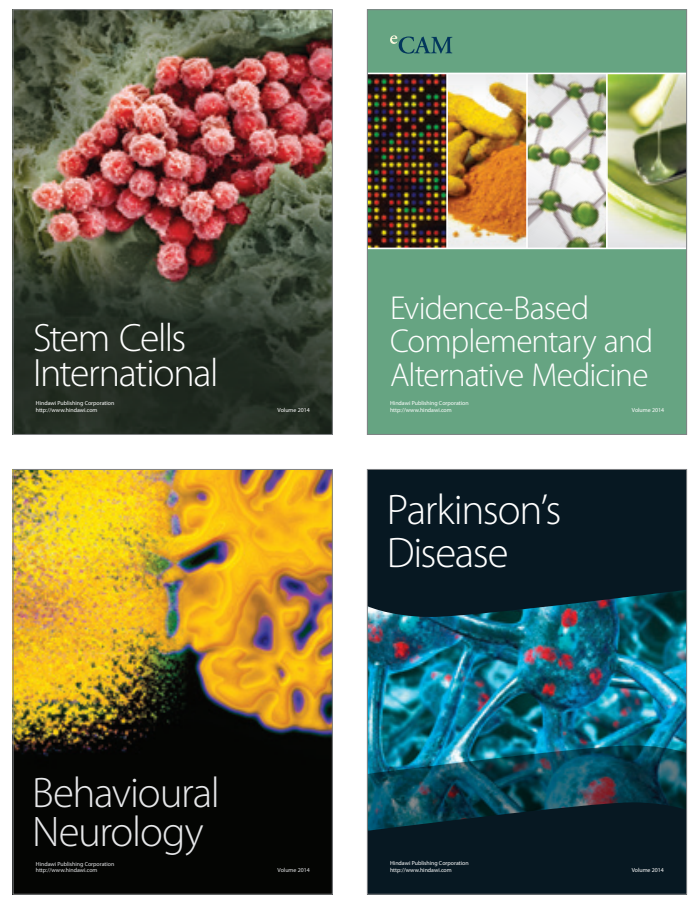
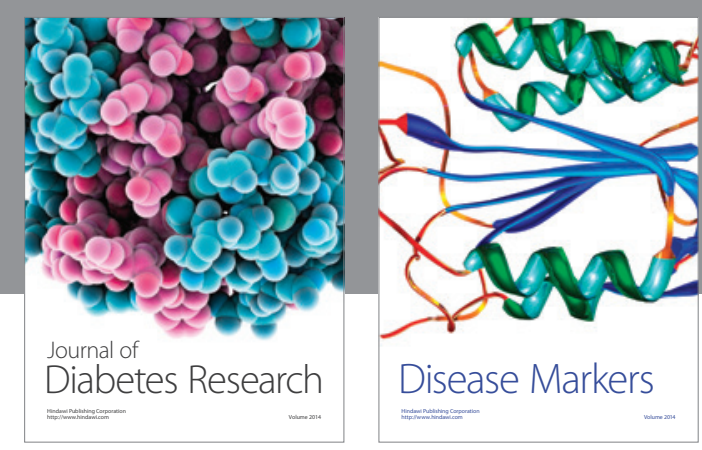

Disease Markers
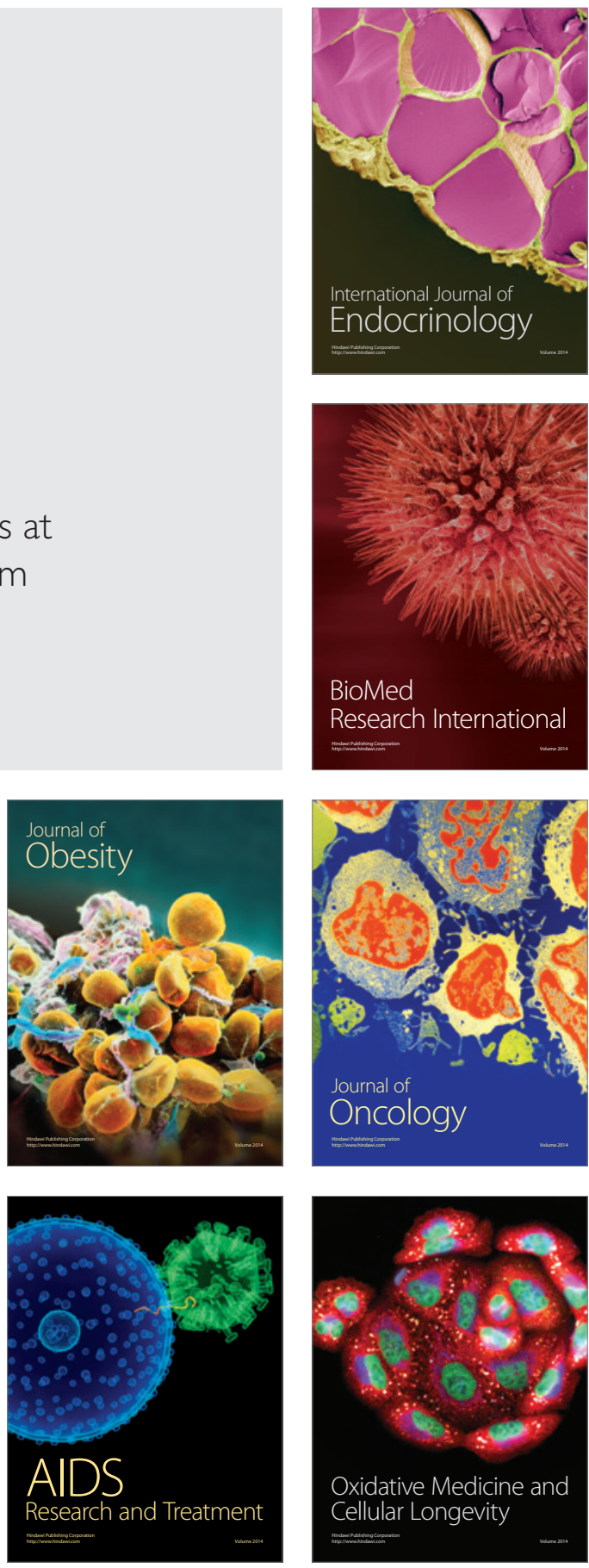